\title{
The digital archival resources on web and the Chinese higher education on world history
}

\author{
Jianghong Fan \\ College of Social Development \\ Yangzhou University \\ Yangzhou, China \\ jhfan@yzu.edu.cn
}

\begin{abstract}
With the arrival of the Age of Big Data, the mass network archival resources attract considerable attention from the world history teachers and researchers in Chinese colleges and universities. This paper focuses on the value and significance, the collecting, the cataloguing and use of the digital archival resources on web for the Chinese higher education on world history.
\end{abstract}

Keywords-education reform; digital archives; world history education; age of big data

\section{INTRODUCTION}

The world of today has entered the so-called the Age of Big Data. Under the support of the rapid development of computer technology, network technology, the mass information from the Big Data has deeply affected people's life, work and thinking. Such phenomenon brought good news for the world history education in colleges and universities in China. The fastgrowing and the vast volumes of the network archival resources are significant in the world history education reform in colleges and universities, which had been realized by the teachers and researchers in China[1][2][3]. Inspired by these scholars research results, this article try to offer a comprehensive discussion of the value and significance, the collecting, the cataloguing and use of the digital archival resources on web for the Chinese higher education on world history.

\section{THE VALUE OF THE NETWORK ARCHIVAL RESOURCES TO THE CHINESE HIGHER EDUCATION ON WORLD HISTORY}

World history education plays an important role in higher history education in China. However, world history education is undeveloped in China compared with the Chinese history education. The reason for the problem is various, while lack of abundant archival resources is a main one. It is generally known that the historical archives are the cornerstone of the history study. If there is no adequate historical archive, there is no high-level history study either. In reality, however, the acquirement of relevant materials on world history is limited by many factors in China. There is a consensus among the world history teachers and researchers in China, that is, lack of abundant archival resources restrict the improvement of the study and teaching of world history in China seriously.

With the rapid development of the computer and the internet, amount of archival resources have been digitalized since the Age of Big Data. Many kinds of digital archives stored in web can be accessed for the teaching and researching of world history. Through the internet, we can easily access digital historical archives in time which will partly solve the problems challenged the world history development for a long time.

The value of huge amount of the digital archival resources to the world history education exists not only in enriching the teaching materials but also help to refresh the teaching model of world history education. Since the new era, there are many reforms in the world history education in China, however, the traditional teaching models and ideas still exist. The practical teaching cannot reach the vivid result for lacking original archival materials; text books and second hand materials are the main teaching resources in the world history education.

The world history education in colleges and universities is different from the education in middle school and exploring learning should be its teaching mission. In the $19^{\text {th }}$ century, the famous Germany historian Leopold Von Ranke invented a teaching model named "seminar", in which the teacher guide the students to research and analysis the researching objects with original archival documents. In this way, the students acquire the knowledge and most important is that they mastered how to acquire the knowledge. In fact, this model is exploring learning model and the original archival materials are the important bases to apply this model.

Rich digital archival resources provide the opportunity for the world history education to get rid of the old traditional teaching idea, at the same time introducing the resources to the practical teaching will lead to the real exploring learning model in the world history education in colleges and universities. Based on the digital archival materials on web, the students will become the subject of the learning but not the passive object in the world history education. With the guide of the instructors, students were required to attend and discover the learning materials, to analysis and deal with the digital archival documents on web. In this manner, the students will be more active, capable and independent in learning and can understand the history well. Thus the students study interest will be increased and teaching quality will be improved too. 


\section{THE COLLECTING OF THE NETWORK ARCHIVAL RESOURCES ON WORLD HISTORY}

In view of the value and significance of the network archival resources, how to collect these resources should be an essential skill for the teachers and students on world history. There are several methods in collecting the network archival resources on world history as below.

Firstly, it is a good choice to collect these resources by the internet search engine. The internet search engine can be divided into regular search engines and academic search engines. Google search, yahoo search, and baidu search are the commonly used as regular searching engine. The user can search the materials with subject, keywords in these search engines, however, the searching will be difficult because it needs the user know the searching materials very well and select right access point words. Compared with the regular search engines, the special academic search engines, for their special target capability, will be more helpful to the users to search the academic materials which are always neglected by the regular search engines.

There are some famous academic search engines: Google scholar search (http://scholar.google.com), Micorsoft academic search (http://academic.research.microsoft.com), Scirus search developed by the corporation of Elsevier Science (http://www.scirus.com), and OAIster search from Michigan University (http://www.oaister.org). We should notice that when using regular search engines and academic searching engine, we often should not just use one of them. For the searching engines can find different databases so single searching will lead to the uncompleted results. Thus, multisearching is necessary.

Secondly, we can acquire the network archival resources through the portal website. The website of About.com can be an example. After entering this website, About Education (http://www.about.com/education), we can find that there are several ways to find relevant information on this site. You may look for a topic in the menu or try using the search feature to search for a topic. Topics are divided into 12 geographical, time period or special topic groupings and are listed in alphabetical order beginning with the Americas and ending with World Religions. We also can use the "Complete Table of Contents” option to locate essays and articles. Biographies of individuals may be found on the page that best represents the era in which they lived. For example, Abraham Lincoln will be found on the American Civil War Page and Hannibal on the Ancient Rome Page.

Thirdly, professional websites for world history researcher are the centers for the network archival resources on world history. The professional websites here mainly refers to the archival material websites that are created and maintained by governmental department or researching organization. Among the websites are both general topic and special subject, which are all provide the archival materials related some historical people, event, period and place. Some examples as below:

\section{(1) The New Deal Network (http://newdeal.feri.org/)}

The New Deal Network (NDN) is an educational guide to the Great Depression of the 1930s. The New Deal Network is sponsored by the Franklin and Eleanor Roosevelt Institute and the Institute for Learning Technologies at Teachers College/Columbia University. NDN is funded in part through a grant from the National Endowment for the Humanities. At the core of the NDN is a database of photographs, political cartoons, and texts (speeches, letters, and other historic documents from the New Deal period). Currently there are over 20,000 items in this database, many of them previously accessible only to scholars.

(2) Margaret Thatcher Foundation (http://www.margaretthatcher.org/)

This website of the Margaret Thatcher Foundation is the largest contemporary history site of its kind. It offers free access to thousands of historical documents relating to the Thatcher period.

The scope of this site is not simply biographical, despite the name. It provides material on the issues that concerned Margaret Thatcher as well as the woman herself. For example, there are key documents from the Cold War like the texts of the Reagan-Gorbachev summits in which Margaret Thatcher played no direct part, but which mattered greatly to her.

Most of the documents are images of the originals, in PDF format. A minority are transcripts. Texts have been machine indexed, including most of the PDFs, so keyword searches should find most documents containing the word. That said, the indexes are not 100 per cent accurate for PDFs. Name and subject indexes have been compiled by hand for greater accuracy.

There is a multimedia section for photos, film and audio material. Public statements like speeches and press conferences can be found in the Speeches section. There are chronology and commentary sections too.

(3) The World Wide Web Virtual Library History Central Catalogue (http://vlib.iue.it/history/index.html)

The original author, Dr. Lynn H. Nelson, launched it on the 21st of September 1993 in the WWW-Virtual Library. This site is now maintained by Serge Noiret at the European University Institute, Florence, Italy. The contents of this site divided into such subject: 19th Century History; 20th Century History; African History; African-American History; Ancient/Classical History; Asian History; European History; Latin American History; Medieval History; Military History; Women’s history.

Fourthly, we can collect the resources what we want through the digital library. Digital library includes the traditional library which provides the digitalized traditional materials and the virtual digital library which only provides the electronica materials. Some examples as below:

\section{(1) The British Library (http://www.bl.uk/)}

With explore the British Library's website you can search, view and order items from its main catalogue of nearly 57 million records. The digitized manuscripts in this site contain many different kinds of manuscripts, archives and documents. There are more than 600 Greek manuscripts ranging in date from the $9^{\text {th }}$ century to the $18^{\text {th }}$ century included in the site. The Harley Science Project makes available images and 
descriptions of 150 medieval and modern scientific manuscripts from the British Library's collection. Botany in British India Project has digitized 120 files from the India Office Records relating to botanical enquiry in India between 1780 and 1860. There are several such projects in the British Library's website.

(2) (http://memory.loc.gov/ammem/index.html)

Memory

American Memory is a gateway to the Library of Congress's vast resources of digitized American historical materials. Comprising more than 9 million items that document U.S. history and culture, American Memory is organized into more than 100 thematic collections based on their original format, their subject matter, or who first created, assembled, or donated them to the Library.

The original formats include manuscripts, prints, photographs, posters, maps, sound recordings, motion pictures, books, pamphlets, and sheet music. Each online collection is accompanied by a set of explanatory features designed to make the materials easy to find, use, and understand. Collections may be browsed individually, searched individually (including fulltext searching for many written items), or searched across multiple collections. The Library's expert research and reference staff is available online to assist patrons in accessing American Memory materials through the Ask a Librarian service.

\section{(3) ipl2: information you can trust (http://www.ipl.org/)}

In January 2010, the website "ipl2: information you can trust” was launched, merging the collections of resources from the Internet Public Library (IPL) and the Librarians' Internet Index (LII) websites.

Lastly, some academic databases can offer us many precious digital historical archives. For this purpose, we need to purchase some special subject databases. Special subject databases are mostly operated by special Commercial Corporation which digitized the traditional documents and provide them to the users who purchase them through web.

Gale is an educational publishing company based in Farmington Hills, Michigan, the United States, in the western suburbs of Detroit. It was part of the Thomson Learning division of the Thomson Corporation, a Canadian company, but became part of Cengage Learning in 2007. The company may be best known for its full-text magazine and newspaper database, InfoTrac, and other online databases accessible from schools and libraries, as well as multi-volume reference works, especially in the areas of religion, history and social science.

The Gale Group owns a variety of databases, including Info, Health Reference Center, and so on. In history study field, the famous databases of "History Resource Center: World" and "Declassified Documents Reference System" belong to Gale Group.

DDRS fills an important gap in American post-World War II domestic and foreign policy studies and provides unique opportunities for undergraduate and graduate comprehensive research in a rich primary source. From many perspectives DDRS illuminates such events and developments as the recognition of the economic and strategic importance of the Middle East, the development of the Cold War and Soviet expansionism, the problem of refugees and displaced persons, the various faces and responses to the end of colonialism in Africa, the economic and social stratification of Latin America, the "miracle" of Western Europe following the devastation and economic collapse of the immediate postwar period, and the application of the "domino theory" in Asia. DDRS is not just for international affairs and foreign policy research. There are significant materials highlighting the political, social, and economic development and forces in post-World War II America. There are documents on the "Communist Scare" of the 1950s; the rise of Black militancy and violence in the 1960s and the white backlash; political and social unrest, particularly the Civil Rights and Anti-War movements; political scandals and abuse of power; the rise of both global and home-grown terrorism; and development of NAFTA and world trade.

DDRS provides user with 100,000 original documents, more than 600,000 pages. These documents originates from the White House and a variety of U. S. government agencies, ie., Central Intelligence Agency, Federal Bureau of Investigation, Defense Department, Justice Department, National Security Council, State Department, etc. The full text of every document has been keyed, allowing specific word, phrase, name or date searches. Special search fields provide more targeted document retrieval options. Easily accessible digital facsimiles can be downloaded and printed as required.

\section{THE CATALOGUING AND COLLATING OF THE NETWORK ARCHIVAL RESOURCES ABOUT WORLD HISTORY}

Generally speaking, the user who knows some world history and English can easily access and acquire the materials through the link on the web. Let us take the website of "International World History Project" as an example. This site contains a collection of world history related essays, documents, maps, music and video archives from the pre-Sumerian period to the present including the history of the ancient world, Africa, Europe, Asia, India, the Middle East, Australia and the Americas. There is a section containing historical documents such as the Magna Carta and the American Declaration of Independence. We also can find some sections relating to world religions, philosophies and scientific discoveries and ideas. After inputting the URL and logging into the website, we can easily find that the database of the web has many access points such as "texts", "keywords", "description", "title" and "subject". If the user has no accurate searching object, the web also provides the arrangement according to subject, place, time and special area. There are 12 subjects: "the Americas", "Africa, Australia and the Sea Islands", "Ancient World”, "Anthropology and Archaeology", "Arts and Architecture”, "Asia and the Middle East”, "Civilization”, "Europe”, "Maps, Great Speeches, Audio and Historical Documents", "Science”, "Women in History", "World Religions". Under these subjects, there are more detail sub-items, and the user can retrieve by different subject and different class and then acquire the materials that can be downloaded in PDF form or TXT form.

Facing the huge amount of the digital archival materials, if we only are busy searching and accessing and not arranging, then we will lost in the data sea. According to the teaching 
contents, instructors can arrange the digital archival resources of world history according to the time, place, subject and nature, and form the special database, which is the premise for effective accessing the resources and set the base for leading the later practical teaching.

Another question that needs to be noticed is that appraisal, checking during the use of the digital archival materials is necessary. Compared with the traditional paper-based archival resources, the digital archival materials on web have the following benefits - huge amount, often refresh, easy retrieval and low cost, but they have some shortcomings at the same time, such as complex contents, unfixed status and irregular values. All these characteristics of the digital archival resources are caused by the nature of the web. So the instructors should select and check the collected digital materials in order to enrich the teaching contents, create the teaching model and ensure the teaching quality simultaneously.

In a word, the abundant digital archival resources provide a useful weapon for the development of world history education in Chinese higher education and should be paid more attention by the Chinese instructors worked in this field.

\section{REFERENCES}

[1] J. R. Benjamin, A Student's Guide to History, Boston and NewYork: Bedford/St. Matin's, 2004

[2] Zhu Xiaoyuan, How to Study World History?, Beijing: Beijing University Press, 2011, pp. 301-330

[3] Liang Zhanjun, "On the Colleting and Use of the Network Resouces about World History Education,” History Teaching, Jun. 2012, pp.69-72. 